\title{
Plant poisoning in Sri Lankan children: A hospital based prospective study
}

\author{
G N Lucas ${ }^{1}$ \\ Sri Lanka Journal of Child Health, 2006; 35: 111-24
}

(Key words: Plant poisoning, children, Sri Lanka, hospital based study)

It was my good fortune to have studied paediatrics under the tutelage of the late Professor C C de Silva. In fact, I belonged to the very last batch of students to have been examined by Professor C C de Silva at the final MBBS examination held in June 1966, just prior to his retirement.

Professor C C de Silva was educated at St Thomas College, Mount Lavinia. After one year at the Ceylon Medical College, he proceeded to the United Kingdom where he passed the MBBS (London) and later the same year, the MRCP (London) examination, truly a Herculean feat. In 1938, he was successful at the MD (London) examination. In 1949, he was appointed to the newly created chair of paediatrics, University of Ceylon, which he adorned for 17 years. He accepted the challenge of organizing and developing the department of paediatrics from scratch and in the process established the first teaching unit at the Lady Ridgeway Hospital. In 1956, the Royal College of Physicians conferred on him the FRCP (London). Professor C C de Silva was a pioneer in promoting breastfeeding and nutrition. In 1956, he established a malnutrition clinic at the Lady Ridgeway Hospital. The booklet "Mother your baby" was jointly authored by Professor C C de Silva and Mrs N Visvanathan. Professor C C de Silva also pioneered home visiting and family planning. In 1954, in association with the late Dr L O Abeyratne, he established the Talagolla Convalescent Home for malnourished children from Ridgeway Hospital. He was elected President of the Ceylon Paediatric Association from 1955 to 1957. In 1961, he was President of the Ceylon Association for the Advancement of Science. In 1975, he was founder President of the Sri Lanka Nutrition Society. In 1983, he received the Doctorate in Science awarded by the Peradeniya University for services rendered to the University and to the academic field at large.

\footnotetext{
${ }^{1}$ Consultant Paediatrician, Lady Ridgeway Hospital, Colombo at the time of the study. Retired from government service in 2001.
}

Professor C C de Silva firmly believed in the aphorism "All work and no play makes Jack a dull boy". Thus, he readily appreciated my participation in a table tennis tournament during my professorial appointment. However, he did not equally appreciate my lack of knowledge about the time required to boil an egg. Professor C C de Silva strode across the paediatric world like a Colossus and there is no doubt that he put Sri Lanka on the international map of paediatrics. When I sat for the MRCP (UK) in 1974, the first question I was asked at the oral was where I hailed from. When I replied "Sri Lanka", the next question was whether I knew Professor C C de Silva. Thus, you can imagine with what esteem he was held abroad. Professor C C de Silva was a prolific writer and his publications in national and international journals are plentiful. He was well versed in music, art and literature. "Out steps the Don" and "Life as I lived it" are two of his non-medical literary efforts. He passed away peacefully on 20th May 1987, soon after he completed his autobiography.

For the Professor C C de Silva memorial oration I have chosen the topic "Plant poisoning in Sri Lankan children, a hospital based prospective study".

\section{Introduction}

Plants have been around for a very long time and are the very essence of life on mother earth. Almost every herb, vegetable and fruit has medicinal properties. 'Walpenela' is used to treat piles, rheumatism and nervous disorders. 'Karapincha' is used to relieve stomach disorders and flavour Sri Lankan curries. 'Karavila' and 'polos' are given to nursing mothers to increase the flow of milk. Cucumber keeps kidneys healthy. Flowers of the 'delun' tree relieve sore eyes. 'Vala' is a laxative whilst 'waraka' benefits diabetics. 'Nelli' is rich in vitamin C. 'Gotukola' is purported to prolong life, as its leaves are commonly eaten by elephants. Numerous skin diseases are treated with 'gotukola' which is rich in vitamin A and folic acid and is commercially available. 'Kohomba' has antiseptic 
properties. Ginger is used as a flavouring agent and medicinal plant.

Plant extracts are widely used in cosmetics. Cocoa butter, mango, coconut oil, sunflower oil, olive oil and castor oil are active ingredients in products formulated for dry skin. Turmeric is used to treat eczema. Extracts from pea, pumpkin and red onion are used to treat acne. Extracts from gingseng, tea and grape seed are used as "anti-ageing" products. Oats are used in facial masks and soaps, to relieve irritation and itching. Aloe vera, henna, sage and rosemary are said to promote hair growth. Sage, rosemary, thyme and garlic are used to treat dandruff. Natural dyes derived from henna are used in hair colourant products. Essential oils like citrus, lavender and sandalwood are used in the perfume industry.

Despite their varied uses, plants are occasionally harmful. For instance, they can cause phytodermatitis. Stinging nettles is an example of non-allergic contact dermatitis where the rash develops in persons not previously exposed to the plant. In allergic contact dermatitis, plant needs to be sensitized by previous encounters. Poison ivy reaction is an example. Another type of allergic reaction is urticaria, which can be caused by strawberries, onions, garlic and tulip bulbs. Foreign body aspiration in the tracheo-bronchial tree involves food items, especially peanuts, in infants and toddlers. 'Kuppameniya' can cause acute intravascular haemolysis in patients with glucose-6phosphate dehydrogenase deficiency. The plant 'Wadakaha' shot to fame in 1955 during the total solar eclipse seen over Ceylon. Dark-skinned Emily fell for the myth that drinking large quantities of a decoction made from the rhizomes of this plant, during a total solar eclipse, lightens the skin. Emily suffered severe bouts of vomiting and spent the next 3 days in Lunawa hospital. This incident is immortalised in the "Baila" song "wadakaha sudiya", one of my favourites.

Children consider plants to be their friends, but, unfortunately, these very same friends sometimes turn out to be their enemies. This happens when poisoning occurs due to children eating fruits, flowers, stems, roots or leaves of unknown plants, being attracted by their colour or smell. Fatalities are rare as the child eats only a few leaves or seeds out of curiosity, spitting or involuntarily vomiting out the contents as soon as he or she feels the funny and irritant feeling in the mouth ${ }^{1}$. In my published study on acute poisoning in Sri Lankan children, poisonous plants accounted for $10 \%$ of the total ${ }^{2}$. Prospective studies of poisonous plants are very scanty. As far as
I am aware, this presentation is the first comprehensive prospective study of plant poisoning in adults or children, virtually a lifetime contribution to the paediatric scientific literature.

\section{Design, setting and method}

A prospective hospital-based study was carried out on children admitted to the Lady Ridgeway Hospital, Colombo, with a history of having ingested a part of a poisonous plant, from June 1984 to December 2001, a period of seventeen and a half years. All cases were seen by me personally and the history obtained from the parent or relative accompanying the child. A complete physical examination was done and appropriate investigations carried out as and when necessary. Children were observed during their hospital stay and the treatment given was noted.

\section{Results}

During the period of study, 243 children were admitted to the Lady Ridgeway Hospital with a history of ingestion of some part of a poisonous plant.

The sex distribution is shown in table 1 .

Table 1

Sex Distribution

\begin{tabular}{|l|c|}
\hline SEX & NO. OF CHILDREN (\%) \\
\hline Male & $148(61)$ \\
\hline Female & $95(39)$ \\
\hline
\end{tabular}

The age distribution is shown in table 2 .

Table 2

Age Distribution

\begin{tabular}{|l|c|}
\hline AGE (years) & NO. OF CHILDREN (\%) \\
\hline $1-3$ & $53(22)$ \\
\hline $4-5$ & $70(29)$ \\
\hline $6-12$ & $120(49)$ \\
\hline
\end{tabular}

The poisonous plants ingested, classified according to their botanical family and name, are shown in table 3 . 
Table 3

Poisonous Plants Ingested

\begin{tabular}{|c|c|c|}
\hline BOTANICAL FAMILY & BOTANICAL NAME & NO. OF CHILDREN (\%) \\
\hline \multirow[t]{4}{*}{ EUPHORBIACEAE } & Jatropha curcas & $57(23)$ \\
\hline & Ricinus communis & 46 (19) \\
\hline & Jatropha multifida & $02(01)$ \\
\hline & Manihot utilissima & $12(05)$ \\
\hline \multirow[t]{3}{*}{$A R A C E A E$} & Dieffenbachia & $28(11)$ \\
\hline & Alocasia & $04(02)$ \\
\hline & Caladium & $02(01)$ \\
\hline PASSIFLORACEAE & Adenia palmata & $23(10)$ \\
\hline$A G A R I C A C E A E$ & Amanita phalloides & $20(08)$ \\
\hline \multirow[t]{2}{*}{ SOLANACEAE } & Nicotiana tabacum & $10(04)$ \\
\hline & Datura stramonium & $07(03)$ \\
\hline APOCYANACEAE & Thevetia peruviana & $14(06)$ \\
\hline$L I L I A C E A E$ & Gloriosa superba & $08(03)$ \\
\hline LEGUMINOSAE & Abrus precatorius & $08(03)$ \\
\hline MYRTACEAE & Eucalyptus robusta & $01(0.5)$ \\
\hline MYRISTACACEAE & Myristica fragrans & $01(0.5)$ \\
\hline
\end{tabular}

Different poisonous plants exert varied toxic effects in children. It is time now to consider in depth some of these plants and their untoward effects.

Jatropha curcas is known as 'purging nut' or 'physic nut' in English, 'weta endaru' or 'rata endaru' in Sinhala and 'adalai' or 'kaitta' in Tamil'. It is called 'weta endaru' because people grow it along fences. It grows as a small tree with undulating five-lobed leaves and yellowish green flowers. Fruit is ellipsoid, scarcely lobed, about $2.5 \mathrm{~cm}$ long and contains some black seeds when ripe ${ }^{4}$ (Figures $1 \& 2$ ).

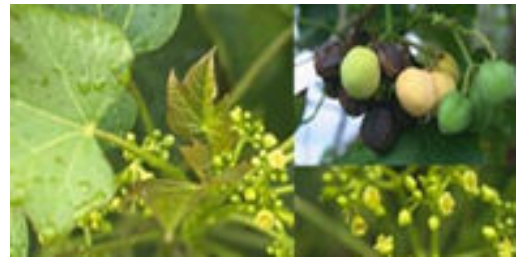

Figure 1 Leaves, flowers \& fruits of 'weta endaru'

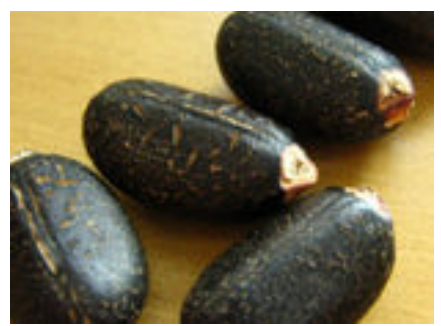

Figure 2 Seeds of 'weta endaru'
Ricinus communis is known as 'castor-oil plant' in English, 'beheth endaru' or 'thel endaru' in Sinhala and 'amanakku' or 'andagam' in Tamil'. Castor oil used for medicinal purposes is non-toxic. It is a soft wooded small tree that grows in most parts of Sri Lanka. Leaves are very large, broad, roundish in outline but partly divided into 7 lobes, the margins being toothed. Flowers are large and are present in big terminal bunches. Fruit has a prickly capsule and is lobulated. Seeds are 5-7 $\mathrm{mm}$ in size, oval, have a brittle covering and are brown in colour with irregular grey spots, resembling a beetle ${ }^{3}$ (Figures $3 \&$ 4).

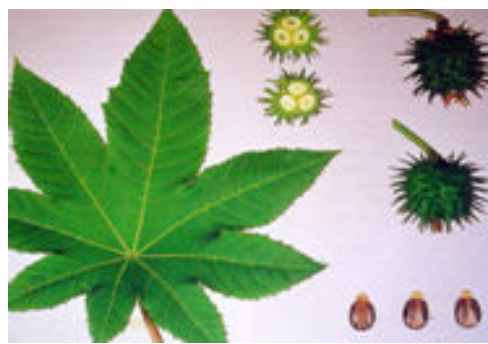

Figure 3 Leaf, fruits \& seeds of 'beheth endaru'

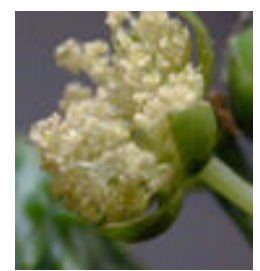

Figure 4 Flowers of 'beheth endaru' 
Jatropha multifida is known as 'coral plant' in English, 'kapum kiriya' in Sinhala and 'malaiya manakku' in Tamil'. It is called 'kapum kiriya' because latex of the plant is applied to wounds and ulcers. It is a large shrub, 2-3 metres high with distinctive large dark green leaves, cut deeply into 711 narrow lobes, margins of each lobe being dissected into narrow pointed segments. Flowers are bright coral red, borne in flat-topped clusters on long stalks held high above the foliage. Fruits are 3 lobed, $2.5 \mathrm{~cm}$ long, smooth and yellowish ${ }^{5}$ (Figure 5).

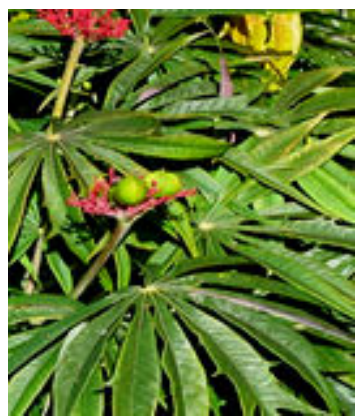

Figure 5 Leaves, flowers \& fruits of 'kapum kiriya'

In my series, 105 children ingested 'weta endaru', 'beheth endaru' or 'kapum kiriya'. Whilst 73 children ingested half to 3 seeds, 32 ingested more than 3 seeds. The latent period before the onset of symptoms ranged from half to 3 hours. The symptoms and signs of poisoning with these 3 plants are shown in table 4.

Table 4

Symptoms and signs of Jatropha curcas, Ricinus communis \& Jatropha multifida poisoning

\begin{tabular}{|l|c|}
\hline SYMPTOM/SIGN & NO. OF CHILDREN (\%) \\
\hline Vomiting & $105(100)$ \\
\hline Dehydration & $65(62)$ \\
\hline Abdominal pain & $30(29)$ \\
\hline Loose motions & $24(23)$ \\
\hline Drowsiness & $21(20)$ \\
\hline Shock & $03(03)$ \\
\hline
\end{tabular}

Emesis was induced with syrup of ipecac in 18 children and gastric lavage was performed in 44 . Intravenous (IV) fluid therapy was needed in 65 cases. There were no fatalities and all of them recovered uneventfully.

Manihot utilissima is known as 'tapioca', 'cassava' and 'manioc' in English, 'manyokka' in Sinhala and 'alavalli' in Tamil ${ }^{3}$. Plant is shrubby, usually with a single, knobbly stem growing to a height of 3 metres and bearing edible tuberous roots. Simple, deeply lobed leaves are alternately placed along stem on long stalks. Flowers are seldom seen as plant is usually uprooted for its tubers long before they develop ${ }^{1}$ (Figures $6 \& 7$ ).

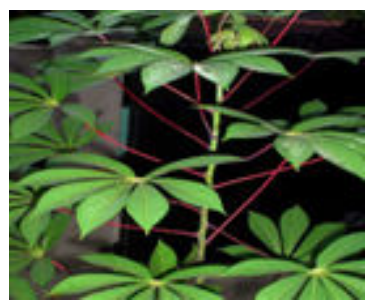

Figure 6 Stem \& leaves of 'manioc'

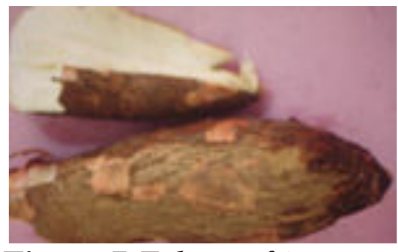

Figure 7 Tubers of 'manioc'

In my series, 12 children ingested 'manioc'. The latent period between ingestion and development of symptoms ranged from 2 to 12 hours. The symptoms and signs of 'manioc' poisoning are shown in table 5.

Table 5

Symptoms and signs of Manihot utilissima poisoning

\begin{tabular}{|l|c|}
\hline SYMPTOM/SIGN & NO. OF CHILDREN (\%) \\
\hline Vomiting & $12(100)$ \\
\hline Abdominal pain & $09(75)$ \\
\hline Dehydration & $09(75)$ \\
\hline Loose motions & $07(58)$ \\
\hline Shock/collapse & $06(50)$ \\
\hline Drowsiness & $06(50)$ \\
\hline Faintness/weakness & $04(33)$ \\
\hline Fever & $03(25)$ \\
\hline Convulsions & $01(08)$ \\
\hline Respiratory distress & $01(08)$ \\
\hline
\end{tabular}

Emesis was induced with syrup of ipecac in one child and gastric lavage was performed in five. Nine children needed IV fluid therapy. Death occurred in a 5 year old boy who had eaten manioc in a boutique near his school and had been given ginger tea on reaching home. 2 hours later, he started vomiting, became drowsy and developed recurrent fits. He was treated in the intensive care unit of the Lady Ridgeway Hospital but died within 48 hours. Specific antidotes such as sodium nitrite, sodium thiosulphate and dicobalt edetate were not administered due to non-availability. 
Many homes contain ornamental houseplants that are not only attractive but also serve as indoor air cleaners. However, some houseplants are hazardous to young children.

Dieffenbachia is called 'dumbcane' in English and 'ketala' or 'kotakimbula' in Sinhala. The name 'dumbcane' is used as the cane-like stem can cause instant "dumbness" when chewed. It is tall, reaching a height of 1-2 metres and has a conspicuously jointed, fleshy, unbranched stem bearing large, simple, erect leaves towards the top. Stems are occasionally mistaken for sugar cane and ingested by children. Leaves are entire and either dark green or variegated green in colour, each with a sheathing stalk $^{6}$ (Figure 8).

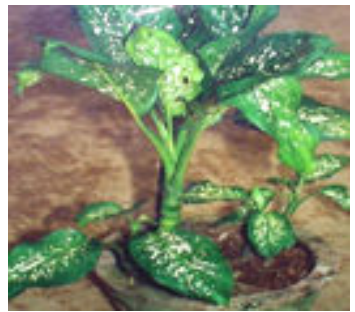

Figure 8 Stem \& leaves of Dieffenbachia

Alocasia is called 'elephant's ear plant' in English, 'habarala' in Sinhala and 'shamakkilangu' in Tamil'. Origin of the name 'habarala' is speculative. During Portuguese times some of the more effeminate Portuguese men carried umbrellas during monsoons. Natives had long used leaves of this plant to protect themselves from rain and it is thought that the Portuguese nancy boys called the plant "Humbrella Plant" which was corrupted to Habarala. It is a robust herb with bright green, large, triangular, sagittate or hastate leaves ${ }^{7}$ (Figure 9).

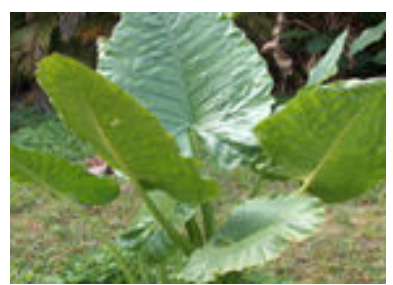

Figure 9 Habarala leaves

Caladium is called 'angel's wings' in English and 'rathu habarala' or 'mal habarala' in Sinhala.. It is an attractive herb with simple, large leaves, variously heart shaped. Leaves resemble small elephant ears and are an assortment of brilliant colours ranging from white to pink to red ${ }^{1,7}$ (Figure 10).

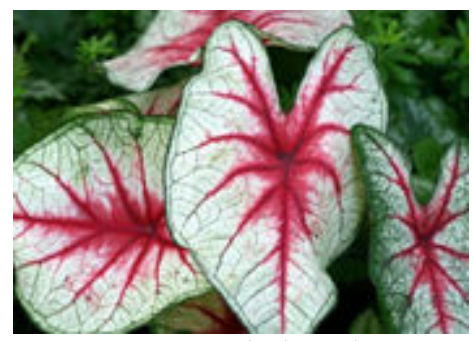

Figure 10 Caladium leaves

In my series, 34 children ingested Dieffenbachia, Alocasia or Caladium. The latent period between ingestion and development of symptoms ranged from half to 2 hours. The symptoms and signs of poisoning with these substances are shown in table 6 .

Table 6

Symptoms and signs of Dieffenbachia, Alocasia and Caladium poisoning

\begin{tabular}{|l|c|}
\hline SYMPTOM/SIGN & NO. OF CHILDREN (\%) \\
\hline Swelling of lips/tongue & $30(88)$ \\
\hline Excessive salivation & $21(62)$ \\
\hline Mouth ulceration & $19(56)$ \\
\hline Itching of mouth & $16(47)$ \\
\hline Vomiting & $06(18)$ \\
\hline
\end{tabular}

Antihistamines were used in 28 children, mouthwashes in 18 and steroids in 4 . All 34 children recovered uneventfully.

Adenia palmata is known as 'hondala' in Sinhala and 'kondala' in Tamil. It is a large aerial plant, climbing by tendrils attached to large trees, growing in the dry and wet zones along forest edges ${ }^{3}$. Leaves have a smooth edge and are divided into 2-5 lobes, the ends of the lobes being pointed. Fruits are spherical, each fruit having a diameter of $4-5 \mathrm{~cm}$. Unripe fruits are green whilst ripe fruits are yellow, orange or scarlet in colour. Fruit divides into 3 equal parts. Inside the fruit are seeds covered with soft jelly like material ${ }^{3}$. The close resemblance of 'hondala' fruit to passion fruit is partly responsible for accidental ingestion by children (Figures 11 \& 12).

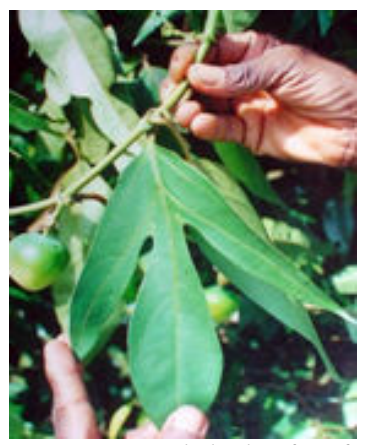

Figure 11 Hondala leaf \& fruits 


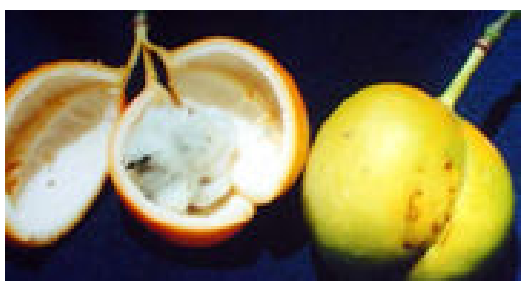

Figure 12 Ripe hondala fruit

Clinical manifestations occur in 3 phases $^{8}$. The first phase, manifests itself with vomiting, fever, restlessness, dizziness, disorientation, abdominal pain and diarrhoea. The second phase of necrotising enteritis, results in diarrhoea with blood and mucus, abdominal colic and tenderness over the right iliac fossa. The third phase, comprising myocarditis, tender hepatomegaly and retinopathy occurs 2-3 weeks after ingestion. In my series, 23 children ingested 'hondala' fruit. The latent period between ingestion and onset of symptoms ranged from 1 to 5 hours. The symptoms and signs of 'hondala' poisoning are shown in table 7 .

Table 7

Symptoms and signs of Adenia palmate poisoning

\begin{tabular}{|l|c|}
\hline SYMPTOM/SIGN & NO. OF CHILDREN (\%) \\
\hline Vomiting & $23(100)$ \\
\hline Dehydration & $16(70)$ \\
\hline Loose motions & $15(65)$ \\
\hline Abdominal pain & $13(57)$ \\
\hline Drowsiness & $10(43)$ \\
\hline Fever & $06(26)$ \\
\hline Dizziness & $02(09)$ \\
\hline Blood in stools & $02(09)$ \\
\hline Shock/collapse & $01(04)$ \\
\hline Convulsions & $01(04)$ \\
\hline
\end{tabular}

Gastric lavage was performed in 10 children and IV fluid therapy given in 16 . Death occurred in a 5 year old boy who developed high fever, vomiting, blood and mucus diarrhoea, drowsiness and fits. Despite IV fluid therapy, blood transfusion and anticonvulsants, the child died. A postmortem examination showed necrotising enteritis.

Poisonous species of mushroom are few but they grow wherever edible varieties are to be found. There is no safe rule-of-thumb to differentiate poisonous from edible mushrooms. Colour is useless, some of the deadliest mushrooms being white. Common folklore such as 'a clove of garlic or a silver object turning black when cooked with a poisonous mushroom', 'removal of "skin" from the cap of a poisonous mushroom making it edible' and 'mushrooms that animals eat being safe for humans', have no basis. Wild mushrooms should not be eaten unless a responsible person recognizes them as safe. There is no place for "experimentation" as there are no antidotes to poisonous mushrooms.

Amanita phalloides is commonly known as 'death cap'. Ingestion of even a small amount of this mushroom may be fatal. It has some resemblance to edible varieties of mushroom but the gills are white or cream and there is a cup-like socket at the bottom of the stem. These two features are useful for differentiating it from edible mushrooms ${ }^{9}$ (Figures 13 \& 14).

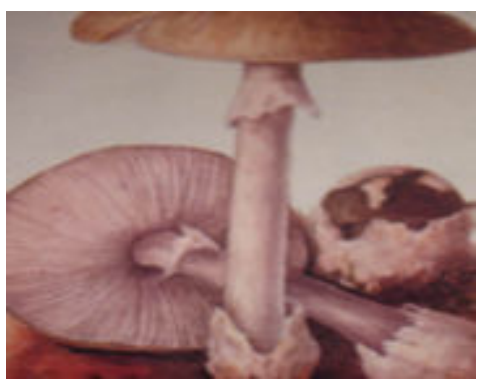

Figure 13 Amanita phalloides

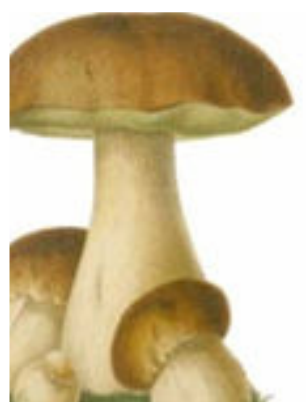

Figure 14 Edible mushroom

In my series, 20 children ingested Amanita phalloides. There was a latent period ranging from 1 to 12 hours between the ingestion of mushroom and the onset of symptoms. The symptoms and signs of poisoning are shown in table 8 .

Table 8

Symptoms and signs of Amanita phalloides poisoning

\begin{tabular}{|l|c|}
\hline SYMPTOM/SIGN & NO. OF CHILDREN (\%) \\
\hline Vomiting & $20(100)$ \\
\hline Dehydration & $15(75)$ \\
\hline Loose motions & $08(40)$ \\
\hline Abdominal pain & $11(55)$ \\
\hline Drowsiness & $03(15)$ \\
\hline Shock/collapse & $01(05)$ \\
\hline Jaundice & $01(05)$ \\
\hline Haematuria & $01(05)$ \\
\hline
\end{tabular}


Gastric lavage was performed in 9 children and IV fluid therapy given in 15 . One child developed hepato-renal involvement with frank haematuria, decreased urine output, jaundice and tender hepatomegaly. Both liver function tests and renal function tests were abnormal. An ultrasound scan of abdomen showed renal cortical damage. Child was referred, after recovery, to Ratnapura General Hospital for follow-up. The other 19 children recovered uneventfully.

Nicotiana tabacum is called 'tobacco' in English, 'dumkola' in Sinhala and 'poyila' in Tamil. Tobacco plant is up to 2 metres high and is covered with soft, sticky hairs. If left to bloom it will produce pink, trumpet-shaped flowers at the top of the $s$ (Figure 15). Use of tobacco leaves in the for 117 cigars and cigarettes or for pipe smoking, chewing or in snuff predisposes to its accidental ingestion by children $^{10}$.

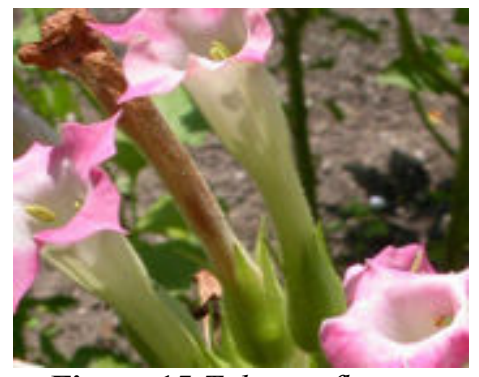

Figure 15 Tobacco flowers

In my series 10 children ingested tobacco. The latent period between ingestion of tobacco and the onset of symptoms ranged from half to 2 hours. Symptoms and signs of tobacco poisoning are shown in table 9 .

Table 9

Symptoms and signs of Nicotiana tabacum poisoning

\begin{tabular}{|l|c|}
\hline SYMPTOM/SIGN & NO. OF CHILDREN (\%) \\
\hline $\begin{array}{l}\text { Impairment of } \\
\text { consciousness }\end{array}$ & $10(100)$ \\
\hline Vomiting & $09(90)$ \\
\hline Diarrhoea & $01(10)$ \\
\hline Dehydration & $01(10)$ \\
\hline
\end{tabular}

Nine children had ingested tobacco powder. The tenth, a 10 year old boy, developed toothache at about $11 \mathrm{pm}$, kept a piece of tobacco leaf on tooth to relieve pain and went to sleep with leaf in situ. In the morning child was found to be unconscious and brought to hospital. Circulatory collapse, a feature of severe poisoning, was not seen. Except for one dehydrated child who required IV fluid therapy, the rest were merely kept under observation.
Datura stramonium is called 'thorn-apple' or 'jimsonweed' in English, 'attana' in Sinhala and 'ayigam' in Tamil. It is a small plant found along roadsides, old fields, pastures and waste places growing to a height of 1-1.5 metres. It has dark green, pointed leaves. Flowers are gramophone shaped and white or purple in colour. Fruit is spherical, $2-3 \mathrm{~cm}$ in diameter and has a sharp spinous capsule that contains 100-200 seeds. Seeds are yellowish-brown in colour, about $3 \mathrm{~mm}$ in diameter and resemble gingelly seeds. Fruits are thorny and attractive, resembling 'rambutan', predisposing to accidental ingestion by children ${ }^{11}$ (Figures $16 \& 17$ ).

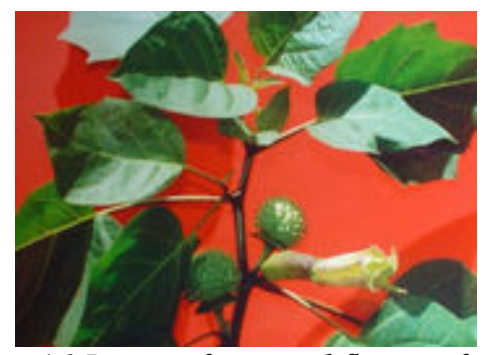

Figure 16 Leaves, fruits and flower of attana

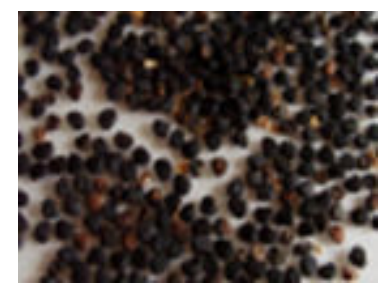

Figure 17 Attana seed

In my series 7 children ingested 'attana'. The latent period between ingestion and the onset of symptoms ranged from 2 to 6 hours. The symptoms and signs of 'attana' poisoning are shown in table 10. Symptoms are well described in the phrase; "hot as a hare, blind as a bat, dry as a horse, red as a beet, mad as a hen".

\section{Table 10}

Symptoms and signs of Datura stramonium poisoning

\begin{tabular}{|l|c|}
\hline SYMPTOM/SIGN & NO. OF CHILDREN (\%) \\
\hline Fever & $07(100)$ \\
\hline Facial flushing & $07(100)$ \\
\hline Pupil dilatation & $07(100)$ \\
\hline Tachycardia & $07(100)$ \\
\hline Delirium & $05(71)$ \\
\hline Dryness of mouth & $04(57)$ \\
\hline Restlessness & $03(43)$ \\
\hline Ataxia & $02(29)$ \\
\hline Abnormal behaviour & $02(29)$ \\
\hline Hallucinations & $01(14)$ \\
\hline
\end{tabular}


Emesis was induced in 2 children and gastric lavage performed in five. Diazepam was used in 4 children. All 7 children recovered uneventfully.

Thevetia peruviana is called 'yellow oleander' or 'lucky nut' in English, 'kaneru' in Sinhala and 'manjal alari' in Tamil ${ }^{12}$. It is often used for hedging and has fuelled suicide rates in Sri Lanka, people often consuming its poisonous seed for the most trivial reasons. Although plant grows widely in the tropics, it is in Sri Lanka that it has become associated with suicide. It is a small tree with a milky sap, growing to a height of 10 metres. Leaves are dark green, glossy, linear, alternating on stem. It has large funnel-shaped, flamboyant, yellow flowers grouped at the end of the branches. Fruits are fleshy, angular, green when immature, yellow to black when ripe, broader than long and somewhat triangular in outline, with a raised ridge around the middle, about $3-4.5 \mathrm{~cm}$ in diameter. Fruit contains 1-3 nut-like seeds $^{12}$ (figure 18).

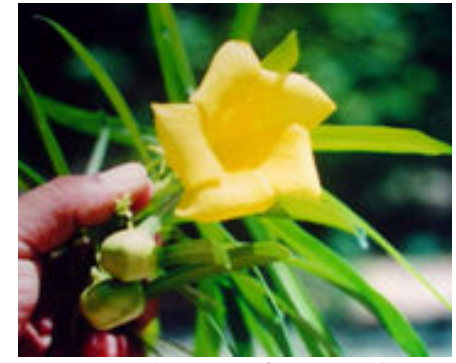

Figure 18 Flowers, fruits \& leaves of yellow oleander

14 children ingested yellow oleander fruit. A 10 year old boy deliberately ingested a yellow oleander seed because he was scolded by his mother for not going to school. Another 10 year old boy deliberately ingested 2 yellow oleander seeds after parents had forced him to study for the $5^{\text {th }}$ year scholarship examination. The other 12 ingestions were accidental. The latent period between ingestion and the onset of symptoms ranged from 1 to 6 hours. Symptoms and signs of yellow oleander poisoning are shown in table 11.

Table 11

Symptoms and signs of Thevetia peruviana poisoning

\begin{tabular}{|l|c|}
\hline SYMPTOM/SIGN & NO. OF CHILDREN (\%) \\
\hline Vomiting & $14(100)$ \\
\hline Bradycardia & $14(100)$ \\
\hline Prolonged PR & $04(29)$ \\
\hline Abdominal pain & $04(29)$ \\
\hline Loose motions & $02(14)$ \\
\hline Ectopic beats & $02(14)$ \\
\hline Convulsions & $02(14)$ \\
\hline
\end{tabular}

Gastric lavage was performed in 12 cases. Although bradycardia was present in all 14 cases and first degree heart block in 4 , all responded to atropine, none requiring temporary cardiac pacing. Anticonvulsant therapy was used in 2 cases. There were no deaths.

Gloriosa superba is called 'glory lily', 'flame lily' and 'tiger claw' in English, 'niyangala' in Sinhala and 'illangalli' in Tamil. It is named after its superb glorious flower. It is very poisonous and is often used by adults to commit suicide. It is thus not surprising that the 'Tamil tigers' in November 2003 adopted it as the national flower of Tamil Eelam. It is a slender climber with simple, grass-like leaves with tendrillike tips which curl round supports, enabling plant to scramble over other plants. Flowers are showy, appearing to be upside down as the six narrow, crinkled-edged petals curve upwards and the six long stamens stick out prominently below. Petals are yellow, turning red with age. Flowers do not normally form fruits ${ }^{5}$. Accidental poisoning may occur as tuber resembles 'arrowroot' or 'hulan kiriya' (Figures 19-21).

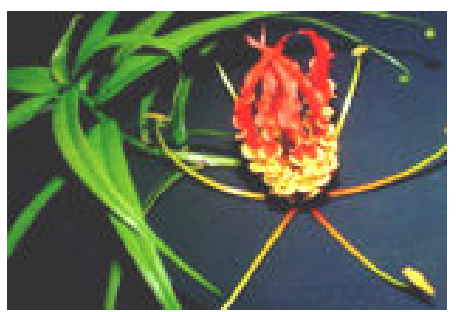

Figure 19 'Niyangala' flower \& leaves

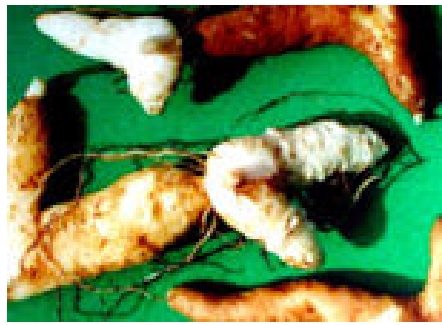

Figure 20 'Niyangala' tubers

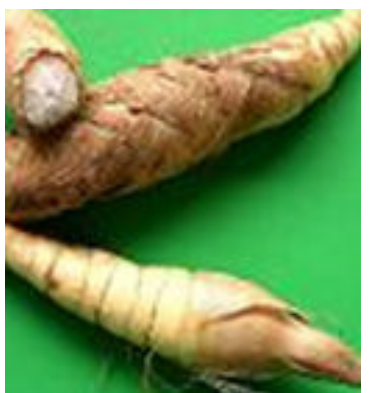

Figure 21 Hulankiriya tubers 
In my series, 8 children ingested 'niyangala'. The latent period between ingestion and the onset of symptoms ranged from 2 to 8 hours. Symptoms and signs of 'niyangala' poisoning are shown in table 12.

Table 12

Symptoms and Signs of Gloriosa superba poisoning

\begin{tabular}{|l|c|}
\hline SYMPTOM/SIGN & NO. OF CHILDREN (\%) \\
\hline Vomiting & $08(100)$ \\
\hline Dehydration & $07(88)$ \\
\hline Drowsiness & $06(75)$ \\
\hline Loose motions & $05(63)$ \\
\hline Abdominal pain & $05(63)$ \\
\hline
\end{tabular}

Emesis was induced with syrup ipecac in 2 children and gastric lavage performed in 5. IV fluid therapy was needed in 6 children. All 8 children recovered uneventfully.

Abrus precatorius is known as 'jequirity-bean' or 'rosary bean' in English, 'olinda' in Sinhala and 'atti' in Tamil. It grows in most parts of Sri Lanka. It is a slender creeper with alternately placed compound leaves. Each leaf has about 20 pairs of narrow, oblong leaflets, looking like a delicate feather. Fruits are short, inflated pods, splitting open when mature, to reveal 3-6 round, hard shiny seeds. Each seed is small, ovoid and scarlet in colour with a black 'eye' at the hilus. The highly attractive seeds are sought after by children for beads. They are sometimes made into necklaces and rosaries. The immature seed is white or pink in colour and is much softer ${ }^{13}$ (Figures $22 \& 23)$.

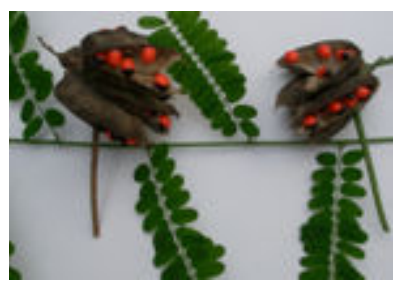

Figure 22 Olinda leaves \& mature seeds

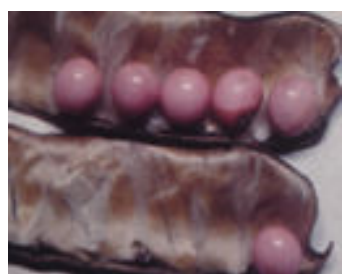

Figure 23 Immature olinda seeds

In my series, 8 children had ingested 3 to 5 immature 'Olinda' seeds. The latent period between ingestion and the onset of symptoms ranged from 1 to 12 hours. Symptoms and signs of 'Olinda' poisoning are shown in table 13.

Table 13

Symptoms and Signs of Abrus precatorius poisoning

\begin{tabular}{|l|c|}
\hline SYMPTOM/SIGN & NO. OF CHILDREN (\%) \\
\hline Vomiting & $08(100)$ \\
\hline Dehydration & $06(75)$ \\
\hline Loose motions & $05(63)$ \\
\hline Drowsiness & $04(50)$ \\
\hline Abdominal pain & $04(50)$ \\
\hline Convulsions & $03(38)$ \\
\hline Retinal haemorrhage & $01(13)$ \\
\hline
\end{tabular}

Gastric lavage was performed in 5 children and IV fluid therapy given in 5. Anticonvulsants were given in 3 children. There were no deaths.

Eucalyptus robusta is called 'swamp mahogany' or 'red gum' and is a very common species planted in estates. It likes swampy, sandy or clayey soils near estuaries or lagoons. It is a medium-sized tree with a rough bark. It has capsular fruit, the top of which comes off as a lid, liberating the seeds. Leaves on mature twigs alternate ${ }^{3}$ (Figure 24).

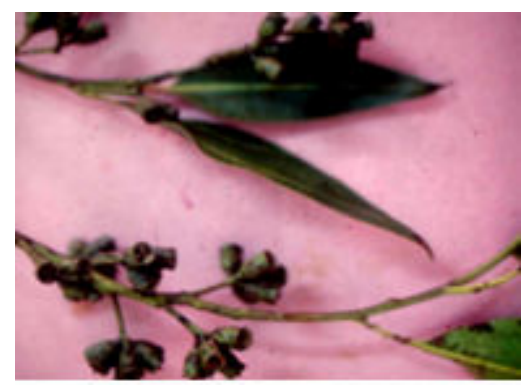

Figure 24 Leaves and fruit of swamp mahogany

In my series, a 6 year old girl ingested Mahogany seeds and was admitted to hospital with flaccid paralysis of all 4 limbs, drowsiness and generalised convulsions. Pinpoint pupils were present with a weak rapid pulse. Gastric lavage was done and IV fluid therapy given. Anticonvulsants were given. Child gradually recovered and was discharged from hospital after 1 week.

Myristica fragrans is commonly called 'nutmeg' in English and 'sadikka' in Sinhala. It is a spreading aromatic evergreen tree usually growing to a height of 5 to 10 metres. Pointed dark green leaves are arranged alternately along branches and are borne on leaf stems about $1 \mathrm{~cm}$ long. Upper leaf surfaces are shiny. Fruits are fleshy, drooping, yellow, smooth, 6 to $9 \mathrm{~cm}$ long with a longitudinal ridge. When ripe, the 
succulent yellow fruit coat splits into 2 valves revealing a purplish-brown, shiny seed surrounded by a red aril (Figure 25). Seeds (nutmegs) are broadly ovoid, 2 to $3 \mathrm{~cm}$ long, firm, fleshy, whitish and traversed by red-brown veins ${ }^{3}$. It is widely used as a spice in various dishes and as a traditional medicine. Children may be at high risk at home, since nutmeg is widely available as a cooking additive.

In my series, a 5 year old girl had ingested 2 nutmegs and a few hours later became restless and started behaving abnormally. On admission to hospital, there was facial flushing, tachycardia and pupillary constriction. Gastric lavage was done and she was kept under observation. Within 48 hours recovery was complete.

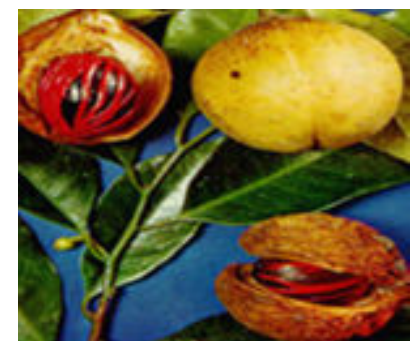

Figure 25 Fruits, leaves, aril \& seeds of nutmeg

\section{Discussion}

The male: female ratio was 3:2. Male preponderance is a feature common to all forms of childhood poisoning in Sri Lanka ${ }^{2}$. The ages ranged from 1-12 years, $78 \%$ children being 4 or more years of age. This contrasts with overall childhood poisoning in Sri Lanka where only $22 \%$ children were 4 or more years of age $^{2}$. This is understandable since older children have more opportunity of ingesting parts of poisonous plants.

Among 243 cases of plant poisoning there were only 2 deaths giving a mortality rate of $0.8 \%$. Except for 2 children who deliberately ingested yellow oleander seeds to teach their parents a lesson, the other 241 cases of poisoning were accidental. This probably accounts for the low mortality in my series.

Accidental ingestion of 'weta endaru', 'beheth endaru' and 'kapum kiriya' accounted for $43 \%$ of plant poisoning. In all 3 plants the toxic element is a toxalbumin named curcin, ricin and jatrophin respectively. Toxalbumins are proteins, which are resistant to intestinal proteolytic enzymes and bind specifically to carbohydrates. Curcin, ricin and jatrophin are found throughout the respective plants with maximum concentration in the seeds. They cause agglutination and haemolysis of red cells and injury to other cells. Ingestion of a single thoroughly chewed bean has caused fatal poisoning. When seeds are ingested with the hard exterior coat intact, toxicity does not occur. Curcin, ricin and jatrophin are thought to be the most toxic substances of plant origin $^{4,14}$. Although $30 \%$ children had ingested more than 3 seeds, there were no fatalities and recovery was complete. Intense vomiting, which invariably accompanied ingestion of these seeds, is probably responsible for the minimal toxicity in my series.

Accidental ingestion of manioc accounted for 5\% of plant poisoning. Toxicity is due to a cyanogenic glycoside, linamarin and the enzyme linase in leaves and root of the plant. Linamarin is present in the autolysable and hydrolysable forms. In the presence of linase, linamarin is autolysed to form hydrocyanic acid. When exposed to the atmosphere, linamarin is hydrolysed and releases hydrocyanic acid ${ }^{15}$. Therefore, old yam (because of exposure) and crushed yam (because linamarin and linase are brought together) are dangerous. However, when yam is cut, washed and cooked at a temperature over $72^{\circ} \mathrm{C}$ in an open container for a sufficient period of time, the enzyme is destroyed and any formed hydrocyanic acid will evaporate. The level of water should be well above the level of yam. Ginger should not be eaten together with manioc as it contains a factor capable of releasing hydrocyanic acid from the glycoside. Consumption of manioc followed by drinking ginger tea is probably responsible for the fatality in my series. These facts are well known to villagers as manioc forms a staple part of their diet, making manioc poisoning a rarity in rural areas.

Accidental ingestion of houseplants accounted for $14 \%$ of plant poisoning. All parts of these plants contain specialised cells in which there are bundles of needle-like crystals of calcium oxalate and toxic proteins ${ }^{1,6,7}$. When plant is chewed, sharp crystals injure the mucous membrane, allowing toxic proteins to penetrate. The extreme oropharyngeal response limits amount of plant ingested making systemic symptomatology improbable. Although there is a risk of oxalate absorption through oral mucosa, systemic poisoning does not occur.

Accidental ingestion of hondala accounted for $10 \%$ of plant poisoning. Hondala fruit contains a cyanogenic glycoside, a toxalbumin and an enzyme emulsin which releases free hydrocyanic acid from the glycoside ${ }^{8}$. When fruit is ingested, free hydrocyanic acid is released in stomach. First clinical phase is probably due to effect of hydrocyanic acid. Second phase is thought to be due to local effects of 
toxalbumin. Third phase is probably due to a hypersensitivity reaction ${ }^{8}$.

Accidental ingestion of Amanita phalloides accounted for $8 \%$ of plant poisoning. Amanita phalloides contains 2 types of toxin: phallotoxins which act rapidly and cause violent gastroenteritis 48 hours after ingestion and amatoxins which have a more delayed effect and destroy cells primarily in the renal tubules and liver. Toxin is resistant to heat and may survive cooking ${ }^{9,10}$.

Accidental ingestion of tobacco accounted for $4 \%$ of plant poisoning. All parts of tobacco plant contain the highly toxic alkaloid nicotine. Nicotine is dangerous as it is rapidly absorbed through skin, lungs and mucous membranes ${ }^{10}$.

Accidental ingestion of attana accounted for 3\% of plant poisoning. All parts of the plant are poisonous but seeds are the most noxious. They contain a number of alkaloids including atropine, hyoscine and hyoscyamine, all having anticholinergic effects. Even a single seed is toxic ${ }^{11}$.

Ingestion of yellow oleander accounted for $6 \%$ of plant poisoning. Whilst 12 children ingested it accidentally, 2 ingested it deliberately. Fortunately, both survived. All parts of plant are highly toxic due to presence of several cardiac glycosides, mainly thevetin A and thevetin B. Ingestion of the kernel of one fruit may prove to be fatal to a child ${ }^{12}$. Currently, about $10 \%$ of adults ingesting yellow oleander in Sri Lanka die after reaching hospital ${ }^{16}$. In fact, antidigoxin Fab fragments are being tried out in Sri Lanka to reverse the serious oleander induced cardiac $\operatorname{arrhythmias}^{17}$. The bitter taste of cardiac glycosides is a deterrent to excessive consumption and the vomiting, which occurs spontaneously, prevents absorption of large amounts of poison. This probably accounts for the absence of mortality in my series but the situation in adults with suicidal intent is quite different.

Accidental ingestion of niyangala accounted for $3 \%$ of plant poisoning. All parts of plant are toxic, particularly the roots. Colchicine, the main alkaloid found in niyangala tubers, is irritant to the bowel, increasing gastrointestinal activity by neurogenic stimulation $^{18}$. It also depresses the respiratory centre, alters neuromuscular function and arrests cell division.

Accidental ingestion of olinda accounted for 3\% of plant poisoning. Seeds are extremely poisonous if cracked; a single cracked seed, if swallowed, can be fatal. Abrin, a toxalbumin found in seeds, causes agglutination and haemolysis of red blood cells and injury to other cells. Mature seed, ingested whole, is innocuous since the harder outer coat is unaffected by digestive secretions. However, chewing, grinding or drilling holes in seed allows contact to occur between intestinal secretions and seed core with possible absorption and toxicity. Immature seed, whose coat is soft and easily broken, is hazardous to children who have difficulty chewing the harder outer coat of the mature seed ${ }^{13}$.

Swamp mahogany contains a volatile oil known as oil of eucalyptus which is the toxic element ${ }^{19}$.

Poisonous parts of myristica fragrans comprise seeds and, to a lesser extent, aril. Volatile myristicin fraction of nutmeg is believed to be responsible for toxicity. Principal effects of nutmeg poisoning resemble those of belladonna alkaloids. An important differentiating feature is the pupillary constriction produced by nutmeg in contrast to pupillary dilatation produced by belladonna alkaloids ${ }^{20}$.

\section{Prevention}

It is important to create awareness of poisonous plants amongst landscape architects and other professionals involved with planting design. Knowledge about poisonous plants should also be imparted to schoolchildren through biology teachers. Media publicity, however, is not an unmixed blessing. In 1980, two schoolgirls in Jaffna committed suicide by eating yellow oleander seeds. Their story was widely reported in local newspapers and appears to have stimulated others to follow their lead. Jaffna hospital admitted 23 cases of intentional yellow oleander poisoning in 1981, 46 in 1982, 103 in 1983 and ever since numbers ingesting yellow oleander have continued to rise throughout Sri Lanka. Prevention is the best strategy to reduce plant poisoning. Following suggestions aimed at prevention are based on common sense, which unfortunately is not such a common attribute.

- Avoid growing plants with known poisonous properties, especially those with poisonous berries or other attractive above ground features in house or garden. Plants with poisonous root systems are less likely to cause problems since roots are not readily visible.

- Become familiar with poisonous plants in your area and home. Know them by sight and name. If you are not sure about the identity of a plant, ask an expert at a plant nursery or garden shop. 
- When purchasing new plants for home or landscape, ask about their potential toxicity.

- Make children aware of potential dangers of poisonous plants.

- Dispose of dead leaves. Even fallen leaves can still contain toxic chemicals.

- $\quad$ Avoid smoke from burning plants. Never burn a contact poisonous plant as the smoke may be as harmful as plant itself.

- Poisonous houseplants should be kept out of reach of young children.

- $\quad$ Store bulbs and seeds out of sight and out of reach.

- Never eat any part of an unknown plant or mushroom. Pick and dispose of mushrooms found in your garden. Some of these mushrooms can be poisonous. Be aware that mushrooms are abundant after rainy weather. Remember that there are no safe "tests" or "rules of thumb" for distinguishing edible from poisonous plants or mushrooms.

- $\quad$ Teach your children at an early age never to put leaves, stems, bark, seeds, nuts, or berries in their mouths. Never assume a child will not eat something because it tastes, smells or looks bad to you. Supervise toddlers and watch what they put in their mouths. Best way to protect small children from plant poisoning is to teach them not to eat any plant parts without adult supervision until they are old enough to be positive that plant is safe to eat.

- Do not make toys or whistles from unknown flowers or trees.

- Do not assume a plant is safe because birds or other animals eat it. Plants eaten by birds and other animals may be poisonous to humans.

- Do not allow children to suck nectar from flowers or make 'tea' from leaves.

- Do not make home-made medicines or decoctions from unknown plants.

- Do not rely on heating and cooking to destroy poisons in plants.
- Do not use flowers or other plant materials for decorations on food or in cooking without knowing their full identity and status of their "edibility."

- Keep children away from plants that have recently been sprayed with weed killer, bug killer or fertilizer.

- Avoid using garden chemicals which leave a toxic residue on grass or shrubs. Do not forget composting. Recycled kitchen and garden waste can be combined to produce the best garden fertilizer at no cost and reduce need for chemical fertilizers.

- There are no really safe herbicides. Only safe alternative to herbicides is to pull out weeds by hand.

\section{Acknowledgements}

I thank the paediatricians of the Lady Ridgeway Hospital for allowing me access to children under their care for this study and the numerous registrars and house officers of the respective medical units for their ungrudging cooperation. I thank Dr Udaya de Silva for allowing me to use some of his slides of poisonous plants, my daughter Dr Nishani, Professor Ravindra Fernando and the National Poisons Information Centre for their invaluable help. Finally I thank Dr B J C Perera for editing my script, despite his busy schedule.

\section{References}

1. Wee Y C, Gopalakrishnakone P. A colour guide to dangerous plants. Singapore; Singapore University Press, 1990.

2. Lucas G N. A hospital based prospective study of acute childhood poisoning. Sri Lanka Journal of Child Health, 2006; 35: 12-19.

3. Jayaweera D M A. Medicinal plants used in Ceylon. Colombo; The National Science Council of Sri Lanka, 1982.

4. Abdu-Aguye I, Sannusi A, Alafiya-Tayo R A, Bhusnurmath S R. Acute toxicity studies with Jatropha curcas. Human Toxicology, 1986; 5 : 269-74.

5. Cairns J F. The medicinal and poisonous plants of India. Jodhpur; Scientific Publishers, 1986. 
6. Drach G, Maloney W H. Toxicity of the common house plant Dieffenbachia. Journal of the American Medical Association, 1963; 184: 1047-8.

7. Covacevich J, Davie P, Pearn J, (editors). Toxic plants and animals. A guide for Australia. Brisbane; Queensland Museum, 1987.

8. Munasinghe $\mathrm{D}$ R, Karunanayake A, Nimalasuriya A, Kodagoda N. Poisoning with Adenia Palmata. Ceylon Medical Journal, 1971; 16: $182-6$.

9. Mitchel D H. Amanita mushroom poisoning. Annual Review of Medicine, 1980; 31: 51.

10. Frohne D, Pfander H J. A Colour Atlas of Poisonous Plants. London; Wolfe Publishing Ltd., 1984.

11. Sudip R. "Atropine intoxication from the ingestion and smoking of Jimson weed (Datura stramonium)". Veterinary and Human Toxicology, 1991; 33: 588-9.

12. Saranapavananthan N, Ganeshamoorthy N. Yellow oleander poisoning: A study of 170 cases. Forensic Science International, 1988; 26: 247.

13. Hart M. "Hazards to health - Jequirity-bean poisoning". New England Journal of Medicine, 1963; 268: 885-6.

14. Challoner K R, McCarron M M. "Castor bean intoxication". Annals of Emergency Medicine, 1990; 19: 1177-83.
15. Kodagoda N, Marcus V, Ambalavaner S. Some observations on the liberation of hydrogen cyanide from manioc. Proceedings of the Annual Sessions of the Sri Lanka Association for the Advancement of Science 1973; $1 ; 38$.

16. Eddleston $\mathrm{M}$, Ariaratnam $\mathrm{C}$ A, Meyer W P, Perera G, Kularatne A M, Attapattu S, Sheriff M H R, Warrell D A. Epidemic of self-poisoning with seeds of the yellow oleander tree (Thevetia peruviana) in northern Sri Lanka. Tropical Medicine and International Health, 1999; 4: 266-73.

17. Eddleston M, Rajapakse S, Rajakanthan, Jayalath S, Sjostrom L, Santharaj W, Thenabadu P N, Sheriff M H R, Warrell D A. Anti-digoxin $\mathrm{Fab}$ fragments in cardiotoxicity induced by ingestion of yellow oleander: a randomised controlled trial. The Lancet, 2000; 355: 967-97.

18. Dunuwille R, Bibile S W, Balasubraminiam K. "Studies on alkaloids of Gloriosa superba tubers using layer chromatography". Proceedings of the Annual Sessions of the Sri Lanka Association for the Advancement of Science, 1966; 1: 7.

19. Glaister J, Rentocil E. Medical Jurisprudence and Toxicology. Edinburgh and London; Livingstone. 1962; 614-40.

20. Payne R B. Nutmeg intoxication. New England Journal of Medicine, 1963; 269: 36. 